\title{
The Impact of Culture and Belief in So-Called Honour Killings A Comparative Study between Honour Murders and other Perpetrators of Violence in Germany
}

\author{
Keywords \\ Honour killings; Psycho-social stress; Culture, Aggression; Beliefs
}

\begin{abstract}
Although the experts assume that, in addition to general psychosocial stress, culture-specific and migration-related factors play a part in the criminal tendencies of migrants, there has not been much research done to date on the special situation of those persons committing honour killings. This study starts from the premise that these perpetrators have a patriarchal-religious mind-set and have developed a conception of "honour". In connection with biographical stresses they are more willing to injure or kill other people if the values and standards they believe in are not respected. We interviewed 41 men with a Turkish background between 18and 35in Germany who had killed other persons who they thought had violated their concept of honour and who then had been convicted of murder or manslaughter ("honour killers"). The two control groups comprised 44 criminals with an ethnic Turkish background who were in prison on charges of using violence without causing death and 40 prisoners who had been convicted of murder or manslaughter for other reasons. To ascertain the respective motives for their actions, we used semistandardised interviews in jails. Compared to the control groups, the group of honour killers revealed significant differences as regards ethnicity and socialisation, structural violence in their country of origin and stresses within the family. We found a correlation between the parameters "reinforcement through the social milieu" and "costbenefit considerations", "ancestry and socialisation" and "structural violence". In the case of the honour killers we found strong patriarchalreligious cognitions with structural violence which triggered actionoriented and target-oriented aggression when the person concerned felt that the standards and values which he believed in, had been infringed.
\end{abstract}

\section{Introduction}

According to the 2010 United Nations Population Fund Activities (UNPFA) at least 5,000 women and girls worldwide are killed annually in the name of honour. These so-called honour killings are not a religious but rather a social phenomenon: It is true that they frequently occur in Islamic countries, yet they are not confined to these $([1,2]$. Women and girls in at least 14 countries are affected, including Afghanistan, Bangladesh, Brazil, Germany, Ecuador, Italy, Jordan, Palestine, Pakistan, Turkey, Iran, Iraq, Lebanon [3,4].

Above all, so-called honour killings occur in traditional societies whose members have a patriarchal-archaic notion of honour linked

\section{Journal of}

Forensic

Investigation

\author{
Kizilhan $\mathrm{Jl}^{1,2^{*}}$ \\ ${ }^{I}$ Institute for Psychotherapy and Psychotraumtology, University of \\ Duhok, Iraq \\ ${ }^{2}$ Institute of Transcultural Health Science, State University Baden- \\ Württemberg, Germany
}

\section{*Address for Correspondence}

Dr. Kizilhan JI, State University Baden-Württemberg Schramberger Str. 26, D-78054 Villingen-Schwenningen, Germany, Tel:4977203906217;Fax: 497720 3906-219; Email: kizilhan@dhbwvs.de

\section{Submission: 19 August, 2019 \\ Accepted: 28 August, 2019}

Published: 03 September, 2019

Copyright: (๑) 2019 Kizilhan Jl, et al. This is an open access article distributed under the Creative Commons Attribution License, which permits unrestricted use, distribution, and reproduction in any medium, provided the original work is properly cited.

to religious elements [5]. In traditional societies with patriarchal values and norms, women embody honour in a narrower sense. The expression of a women's honour, and therefore the family's honour, is sexual integrity, i.e. chastity and being faithful in marriage. The whole family, represented by the head of the household as the boss, is responsible for the maintenance of women's honour [6]. In patriarchal societies honour is closely connected to sexuality. Extramarital sexual activity endangers the social order: This is why Islam gives clear instructions on how men and women are to behave within and outside marriage [7].

The top priority - and the men's task - is the protection and preservation of honour. As head of the household the father must ensure that the family's honour is protected in public. The sons see themselves - and are brought up in this way - to be their sisters' protectors, protectors of their honour, which could be violated, for example, by their relationship with a man $[8,9]$. This constant fear and insecurity results in the brothers' exercising control over the young girls and sometimes even monitoring their movementsparticularly in an environment which is differently oriented from a religious-cultural point of view. This can have a considerable influence on the relationships between the siblings and in the whole family [10]. Since there is a homogeneous set of values in traditional village communities, such controls are not as necessary as in other environments, and breaches of the rules are quite rare.

In the case of so-called honour killings, for example the German Criminal Code does not explicitly refer for exemaple to human rights, but rather discusses morality and legality, and can classify them as deviating values of a cultural minority, e.g. " honour killings ". Moral beliefs of the perpetrator that contradict those of the majority are just as irrelevant in criminal law as ideas that overlap with those of the majority. Honour killings are seen as murders and sentenced according to the German Penal Code [11].

In many other countries, the so-called honour killings still were not treated as a violation of human rights but were treated as normal 
crimes by the respective national legislators. It is only the pressure from numerous human rights organisations during the last years which has brought about a greater readiness to view this issue from the perspective of human rights [12]. For example, over the last ten years in Turkey some civil rights movements have dealt more intensively with the topic. On 08.03.2005 the Turkish newspaper Hürriyet reported on the work of KAMER, the women's centre in Diyarbakir, and that up to then some 6,902 women had been to the centre to report violence in the immediate or in the extended family. According to information provided by the centre, $100 \%$ of these women were suffering from mental health problems; some $58 \%$ had suffered physical violence and $13.7 \%$ had experienced rape. More than 65 women with strong suicidal tendencies had sought help at the centre, 63 of these are being accommodated in an unknown and safe place because of the fear that they could be killed on account of the possible violation of honour and blood vengeance. In a study conducted by the University of Diyarbakir in 2005, 430 people were asked about the topic of honour killing. $78 \%$ men and $22 \%$ women were randomly chosen from one of the more affluent parts of the town. They were asked what should be done if a woman enters into an extramarital affair with a man. $37.4 \%$ advocated having the woman killed. However, $16 \%$ called for only a punishment. The punishment under consideration was physical injury and mutilation e.g. cutting the ears or the nose. Regarding the question as to who should inflict this punishment, $64 \%$ voted for the husband. $25 \%$ of those interviewed advocated divorce through the proper legal channels [13].

Such honour killings are not only carried out in the home country, but also in the country of migration. According to a Federal Criminal Police (2011), between 1996 and 2005 in Germany alone, at least 55 such murders and attempted murders took place, with a total of 70 victims, of which 48 were female and 22 male. 36 women and 12 men were killed [14]. The killers considered that the female victims had had an extramarital affair, either before marriage (virginity) or with a man of a different religion. The male victims, as a rule, were murdered by members of the woman's family or other close family members of the woman with whom they had had an affair. There are isolated cases of female killers. They kill for the same reasons, namely what they believe to be a violation of honour $[15,16]$ reports that the perpetrators say they felt a deep inner urge to carry out the act and that they had lost their inner peace, that the other person had challenged them and that they would have lost their own honour if they had not carried out the act. From what we can conclude from this investigation we can say that, as a rule, the perpetrators give emotional and psychological reasons for their acts. Honour killings for material, political or religious reasons were not considered [17].

\section{Possible approaches from a criminal-psychological perspective}

Criminal-psychological research tries to understand acts of violence, amongst other things, as the result of an interactive process involving the personality of the individual perpetrator and the facts of the situation at the time [18]. The present study uses the action-theoretical and motivation-psychological models and the interpretations of several authors. These can possibly explain some differences regarding the planning, the controlled implementation and the emotional state before and after the act, in the case of bodily harm, robbery or the emotional intimacy to the victim [1921]. Common to these approaches, crimes can be considered as acts which serve to reach a target and/or to solve a problem. [22] showed, for instance, that young murderers decide to commit an act at short notice and do not plan carefully over a longer time. [23-25] made it clear that robberies were often prepared without considering any details and at short notice. The perpetrator, however, usually believes that he planned the act thoroughly. [20] established the link between poor preparation and the use of violence. He explained that the escalation which is often observed in acts of violence was due to poor preparation. According to Simons, the pressure to act makes the perpetrator hurry and gives him no time to prepare. This and other investigations show how important it is to include actiontheoretical concepts in order to make criminal acts of violence more understandable [26-28]

In the scientific literature, criminal acts of violence are understood as a sub-group of violent actions. Violent actions in turn can be understood as a sub-section of aggressive actions. The border between aggression and violence is not clear; the concept of "violence" tends to be reserved for extreme forms of aggressive actions, that is, for aggressive actions leading to the greater probability of significant injuries to the victim [29]. As a sub-group of violent actions, criminal acts of violence comprise violent actions forbidden by the state under the threat of punishment. In criminology literature, a "criminal act" is frequently referred to simply as a "crime". According to [30], crime is an extremely valueless and socially deviant kind of behaviour. The various forms of crime are defined in legal terms in the criminal code (StGB); this investigation is oriented towards the legal definitions contained in the code.

The reasons for committing a criminal offence are many, for migrants and indigenous people alike. In various studies, cultural and migration-related stress has also been discussed [31]. The deprivation theory as an explanatory approach focuses in particular on the migrants' socio-structural situation. The argument goes that they are often disadvantaged since they more rarely have secondary education qualifications and are employed in the low-paid sector. This is not only a problem because they earn below-average wages but also because their jobs are less secure. For this reason migrants are more often affected by unemployment and receive social security benefits.

They are not able to reach their personal targets by their own means. This causes frustration and is compensated for by acquiring the necessary means in a different way, among other things by robbery and theft [32]. The theory assumes that migrants are more conspicuous and attract attention because of their marginalised social situation. In the same situation German people would probably behave in exactly the same deviant way.

Cultural explanations augment this point of view. They concentrate not only on the marginalised economic situation but also on specific orientations within the migrant groups. According to the sub-culture theory and the theory of cultural conflict, not all the norms and values of a society are valid to the same degree in all social circles. This can be amply illustrated by considering the understanding of honour, as discussed earlier. Migrants do not simply drop such cultural convictions when they come to Germany. To date there have been no scientific studies on the perpetrators who have killed 
Citation: Kizilhan JI. The Impact of Culture and Belief in So-Called Honour Killings A Comparative Study between Honour Murders and other Perpetrators of Violence in Germany. 2019; 7(1): 7.

ISSN: $2330-0396$

Table 1: Composition ofdemographic variables of the three groups.

\begin{tabular}{|c|c|c|c|}
\hline & Violence not resulting in death & So-called honour killers & Murder or manslaughter for other reasons \\
\hline & 44 men $(36 \%)$ & 41 men $(33 \%)$ & 40 men $(31 \%)$ \\
\hline Age & $23.5(\mathrm{SD} 5.1)$ & $34.4(\mathrm{SD} 11.4)$ & 29.4 (SD 9.2) \\
\hline Years at school & 6.1 (SD 4.6) & $5.1(\mathrm{SD} 3.5)$ & 5.7 (SD 4.7) \\
\hline Migration (years resident in Germany) & $19.1(\mathrm{SD} 8.2)$ & $21.3(\mathrm{SD} 7.5)$ & 21.7 (SD 8.7) \\
\hline Perpetrators had history of mental illnes & $2(x \%)$ & 0 & $3(x \%)$ \\
\hline
\end{tabular}

somebody whom they believe has violated honour. For this reason, in this study we want to investigate, by means of direct questioning, the cognitive processes, the possible stress factors and the purpose of the crime. The Rubicon model of action phases [33] was used as a framework model with special reference to honour killers. The model uses four definable phases which are necessary to reach a desired aim. They are choosing, planning, enacting and evaluating, in each case with a specific mind-set. The concept of the "pre-scene" by [34] was complemented in order to provide some inner structure to the enaction phase.

Owing to the perpetrators' cultural and ethnic background we have extended the four phases which [35] suggests. We have increased the action-psychological aspects by a personality-psychological perspective based on [36] and expanded this appropriately for the test persons.

\section{Method}

\section{Random Test}

For purposes of comparison we questioned 65 male test persons of Turkish descent about the crime they had committed and their biographical details. The random test was divided into the following three categories of crime: so-called honour killers $(\mathrm{N}=21)$, violence not resulting in death $(\mathrm{N}=24)$ and murder or manslaughter for other reasons $(N=20)$. In the case of the last group we tried to exclude any possibly latent honour killing by means of pre-interviews and inspection of the person's file. The so-called honour killers were convicted pursuant to $\$ \$ 211$ and 212 of the criminal code (StGB), the group violence not resulting in death pursuant to $\$ \$ 223,224,226,229$ and 231 of the criminal code and the group murder or manslaughter for other reasons pursuant to $\$ \$ 211$ and 212 of the criminal code. To enable a better comparison of the groups and to avoid any possible interferences (ethnic and religious differences as regards values and norms such as a different understanding of honour in the case of the Alevs or other non-muslim groups from the Middle East etc.), we selected only ethnic Turkish perpetrators belonging to the Sunni faith. No female test persons were found for the group investigated.

At the time of the investigation the test persons were in prison and were interviewed there. They had all committed their crime aged between 18and 35years old. As the reason for their action the honour killer group gave the violation of honour as they perceived it; the group violence not resulting in death substantiated their actions with uncontrolled aggression (43\%), robbery and deception (33\%) and relationship problems (24\%). Violations of honour which could possibly have been the cause of the crime in both control groups were excluded by means of pre-interviews and by consulting the case files. The group murder or manslaughter for other reasons gave robbery and deception (60\%) and uncontrolled aggression $(40 \%)$ as the motive for their crime.

The mean age of the ethnic Turkish group of honour killers was 34.4 years $($ standard deviation $=10.4$ ); the youngest person was 18 , the oldest 40 . The mean age of the murder or manslaughter for other reasons group was29.4 years $(S D=9.2$ ); the youngest was 20 , the oldest 36. The violence not resulting in death group had a mean age of 23.5 years $(\mathrm{SD}=5.1)$; the youngest person was20, the oldest 33 .

The honour killers group had attended school for an average of5.1 years, the group murder or manslaughter for other reasons 5.7 years and the group violence not resulting in death 8.1 years. The honour killers group had been living in Germany for an average of 21.3years, the murder or manslaughter for other reasons group for 21.7years and the violence not resulting in death group for 19.1years. In the group violence not resultign death 2 Person and in the group murderoder mansllaughter 3 Persons had a history of mental illnes without any effect on their judgment or live in prison (Table 1). The court files gave information on the type and method of killing and the relationship of the perpetrator to the victim. The violence not resulting in death group had no family ties to the victim and the instruments were so varied and numerous that we could not adequately compare them with the other two groups.

\section{Data Material and Processing}

The data on which the analysis is based was gathered between May 2018 and May 2019. This time span was necessary in order to locate the so-called honour killers via the courts and prisons, to overcome the many legal hurdles and to obtain the perpetrators' consent to being interviewed (Table 2). Test persons for the group to be investigated were found by means of media research, contact to

Table 2: Relationship of perpetrator to victim and method of killing.

\begin{tabular}{|c|c|c|}
\hline & $\begin{array}{c}\text { Honour killers } \\
(\mathbf{n = 4 1 )}\end{array}$ & $\begin{array}{c}\text { Murder or manslaughter } \\
\text { for other reasons (n= 40) }\end{array}$ \\
\hline Relationship to victim & $\%$ & $\%$ \\
\hline Husband/Partner & $49 \%$ & $14 \%$ \\
\hline Other relative & $20 \%$ & $19 \%$ \\
\hline Father & $14 \%$ & $5 \%$ \\
\hline Brother & $17 \%$ & $5 \%$ \\
\hline No relation & $5 \%$ & $53 \%$ \\
\hline Method & & \\
\hline Gun & $39 \%$ & $19 \%$ \\
\hline Knife & $34 \%$ & $16 \%$ \\
\hline Other object & $15 \%$ & $0 \%$ \\
\hline Strangulation & $5 \%$ & $15 \%$ \\
\hline Other physical violence without & $10 \%$ & \\
\hline using an instrument & & \\
\hline & & \\
\hline
\end{tabular}


Citation: Kizilhan JI. The Impact of Culture and Belief in So-Called Honour Killings A Comparative Study between Honour Murders and other Perpetrators of Violence in Germany. 2019; 7(1): 7.

ISSN: $2330-0396$

Table 3: The 14 Quasi Scales and their Thematic Areas.

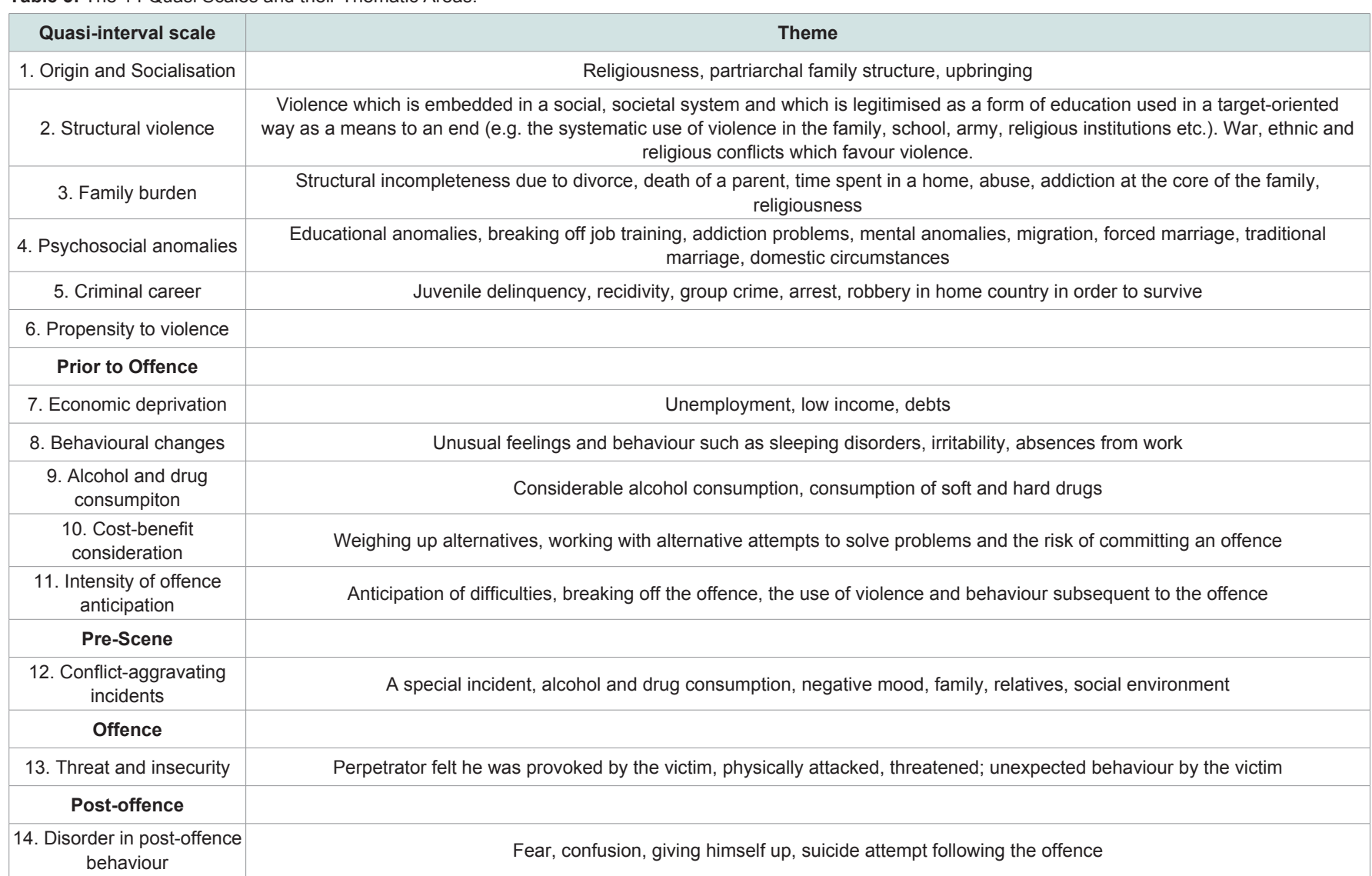

expert testifiers and judges. Those test persons in the groups who said they had not carried out a crime on account of a perceived violation of honour were excluded from the study. With the help of a semistandardised interview, we asked a total of 65 perpetrators in various prisons in the whole of Germany about the crime they had committed and about their biographical background. Prior to this, we looked at the court sentences. To enable a statistical analysis, answers were coded and dichotomised according to fixed contextual criteria. The variables obtained were summarised as per [37] and later according to [38] according to thematic considerations in 14 quasi scales (Table $3)$.

We also considered the variable reinforcement by the social environment. We included this variable if the social environment (family, relatives, friends or members of a community) reinforced the test person's intentions, praised him for his actions during his time in prison or during the court hearing and gave him recognition (e.g. a visit from his family of origin, presents etc.).

The choice of variables which we considered relevant were based, in particular, on the work of [39-41]. We added questions which oriented towards the Rubicon model of action phases of [42] and expanded them to include culture-specific aspects. We devised open and closed interview questions for each topic area which we considered relevant. The answers to the closed interview questions were binary coded. For example, if the answer to the question "Has anybody in your family been in prison?" was "Yes", we coded it with a "1", and for "No", we coded it "0". The coded answers then formed the variable for the "Imprisonment of family members" item. Whenever possible, the criterion variables constructed in this way were then summarised according to content and statistical criteria to form quasi scales ("feature groups"). By summarising the individual features to make quasi scales, each test person could be given a total score for each quasi scale. The groups were then compared based on the total scores. For the scale level of the quasi scales we adopted the ordinal scale. After we had compiled the quasi scales according to content critera, we carried out an item analysis to establish the legitimacy of these post hoc compiled feature groups. As a measure of the inner consistency, we calculated the selectivity (degree of separation) of the individual features and as the form of the reliability analysis for each quasi scale Alpha according to Cronbach. The statistical comparison of the groups on the 14 point quasi scale was done with a ranking test for ordinally-scaled variables (Chi2 - test as per van-der-Waerden) on the 5 per cent significance level.

\section{Results}

Comparison of the three perpetrator groups regarding biographical stress factors

The ranking comparison regarding the accumulation of biographical stress features led to a significant result in all three groups investigated. The honour killers reported religious-patriarchal notions to a significantly more frequent degree, saying that to uphold and maintain honour had been at the centre of their upbringing (recorded on the quasi scale Origin and Socialisation). At the same 
Citation: Kizilhan JI. The Impact of Culture and Belief in So-Called Honour Killings A Comparative Study between Honour Murders and other Perpetrators of Violence in Germany. 2019; 7(1): 7.

\section{ISSN: 2330-0396}

Table 4: Medians of thenumber of applicable features for the six scales on the perpetrators' biographical features.

\begin{tabular}{|c|c|c|c|c|}
\hline $\begin{array}{c}\text { Quasi scale (number of } \\
\text { variables) }\end{array}$ & Violence not resulting in death $N=44$ & $\begin{array}{l}\text { Honour killers } \\
\qquad N=41\end{array}$ & $\begin{array}{l}\text { Murder or manslaughter } \\
\text { for other reasons } \\
\qquad N=40\end{array}$ & $\mathrm{Chi}^{2}(\mathrm{df}=2)$ \\
\hline Origin and Socialisation (11) & 6 & 8 & 6 & $\begin{array}{c}20.7 \\
p=.00\end{array}$ \\
\hline Structural violence(12) & 4 & 12 & 10 & $\begin{array}{c}31.4 \\
p=.00\end{array}$ \\
\hline Family burdens $(10)$ & 6 & 2 & 6 & $\begin{array}{c}20.7 \\
p=.00\end{array}$ \\
\hline Psychosocial anomalies (11) & 10 & 6 & 12 & $\begin{array}{c}31.4 \\
p=.00\end{array}$ \\
\hline Criminal career $(6)$ & 6 & 2 & 10 & $\begin{array}{l}51.8 \\
p=0\end{array}$ \\
\hline Propensity to violence (5) & 4 & 8 & 4 & $\begin{array}{c}39.1 \\
p=.00\end{array}$ \\
\hline
\end{tabular}

Table 5: Medians of the number of applicable features for the scale "cost-benefit consideration" and "intensity of offence anticipation".

\begin{tabular}{|c|c|c|c|c|}
\hline & $\begin{array}{c}\text { Violence not resulting in death } \mathrm{N} \\
\qquad=44\end{array}$ & Honour killers $\mathrm{N}=41$ & $\begin{array}{l}\text { Murder or manslaughter for other reasons } \\
\qquad N=40\end{array}$ & $\mathrm{Chi}^{2}(\mathrm{df}=2)$ \\
\hline Cost-Benefit Consideration (6) & 6 & 2 & 2 & $20.2 p=.00$ \\
\hline Intensity of offence Anticipation (5) & 4 & 0 & 0 & $35.2 p=.00$ \\
\hline
\end{tabular}

Table 6: Medians of the number of applicable features forscale 12 "conflict-aggravating incidents", scale 13 "features of threat and insecurity" and scale 14 "disorder in post-offence behaviour".

\begin{tabular}{|c|c|c|c|c|}
\hline & $\begin{array}{l}\text { Violence not resulting in death } \\
\qquad N=44\end{array}$ & Honour killers $\mathrm{N}=41$ & $\begin{array}{l}\text { Murder or manslaughter for other reasons } \\
\qquad N=40\end{array}$ & $\mathrm{Chi}^{2}(\mathrm{df}=2)$ \\
\hline $\begin{array}{l}\text { Features of threat and insecurity } \\
\qquad(6)\end{array}$ & 0 & 8 & 6 & $\begin{array}{l}35.9 \\
p=.00\end{array}$ \\
\hline Conflict-aggravating incidents (5) & 2 & 4 & 2 & $\begin{array}{c}23.4 \\
p=.00\end{array}$ \\
\hline
\end{tabular}

time, many of these test persons said they had experienced violence at the hands of soldiers, the army, parents or teachers in their home country (Table 4).

\section{Cognitive features, behavioural patterns and incidents preceding the offence}

The statistical comparison of the three perpetrator groups regarding conflict-aggravating incidents and behaviour preceding the offence led to significant results in respect of the scale cost-benefit considerations, changes prior to the offence and intensity of offence anticipation (Table 5). There were no significant results in respect of alcohol and drug consumption preceding the offence and economic deprivation.

\section{Threat and Insecurity}

The three perpetrator groups differed significantly regarding conflict-aggravating incidents (Scale 12) in the pre-scene, features of threat and insecurity(Scale 13) and disorder in post-offence behaviour(Scale 14) (Table 6).

\section{Social Environment}

We also investigated reinforcement from the social environment. Here there was a significant connection between the feature reinforcement from the social environment and the scaleres toring honour and structural violence (Table 7). Table 6: Medians of the number of applicable features for scale 12 "conflict-aggravating incidents", scale 13 "features of threat and insecurity" and scale 14 "disorder in post-offence behaviour"

\section{Discussion}

The ranking comparisons for the accumulation of biographical stress factors indicate that the three perpetrator groups were exposed to varying degrees of unfavourable socialisation conditions. For the group murder or manslaughter for other reasons severe stress was prevalent in all the biographical areas under investigation. In contrast, the group violence not resulting in death had the fewest biographical stress factors. The honour killers revealed the highest degree of stress above all in the case of structural violence. These test persons had also had a strongly patriarchal-religious upbringing. The benefits of restoring honour by means of the offence and thereby getting recognition from the social group had a higher value than the risk of being arrested and possibly being economically disadvantaged as a result. The links between reinforcement from the social environment and the scales restoration of honour and structural violence revealed important effects. Increased unfavourable biographical peculiarities in the case of the honour killers compared to other perpetrators were not confirmed, since the perpetrators of violence not resulting in death, especially when comparing family stress factors and the features of their criminal career, also revealed high values. The key to understanding perpetrators who kill somebody whom they 
Citation: Kizilhan JI. The Impact of Culture and Belief in So-Called Honour Killings A Comparative Study between Honour Murders and other Perpetrators of Violence in Germany. 2019; 7(1): 7.

ISSN: $2330-0396$

Table 7: Correlation Matrix.

\begin{tabular}{|c|c|c|c|}
\hline Feature & Scale"Cost-benefit considerations" & Scale"Origin and socialisation" & Scale"Structural violence" \\
\hline Reinforcement from the social environment & $0,33^{*}(N=41)$ & $0,30(\mathrm{~N}=41)$ & $0,40^{*}(N=41)$ \\
\hline
\end{tabular}

believe has violated honour could possibly be found however in the patriarchal-religious upbringing of those concerned together with violence as an educative method in the broader society (school, army, parents, war zone) in their country of origin. With regard to the scales of weighing up the consequences (cost-benefit considerations) and planning the crime (intensity of offence anticipation), the results showed a division into two of the three perpetrator groups. In the days and weeks before the crime the honour killers thought more elaborately about their crime than the other two groups. We assume that the collective contributes in a decisive way to the crime in the case of a perceived violation of honour. The subsequent perpetrator is much more preoccupied with the possible offence in his environment and the discussion in the community regarding violation and restoration of honour finally leads to the enaction of the crime $[43,44]$. The group murder or manslaughter for other reasons was also primarily concerned with the planning and possible consequences, albeit significantly less than the honour killers. They displayed a less emotional approach, weighed up various alternatives, in some cases thought intensively about the risk of the crime and the punishment and imagined the course of the act and any problems and obstacles which might arise there from [45]. The group violence not resulting in death thought less about the possible consequences of the crime. These consequences hardly seemed to have been anticipated and planned, but displayed the characteristics of a spontaneous "impulsive act". The less the course of the act was anticipated and the less was thought about the cost-benefit aspect, the more likely it was that, after the act, the perpetrator was reminded by unexpected events later which made him insecure. From a theoretical point of view this can be interpreted by the fact that the honour killers used violence from the standpoint of an expected event and experienced fewer target conflicts. Accordingly, the perpetrators behaved more calmly and less chaotically after the act. In general we can, with care, assume that crimes carried out on the basis of a perceived honour violation lead to fewer situations of surprise from which further acts of violence can develop [46]. It appears difficult to prevent such acts since the perpetrators are in most cases directly related to the victims and have shown hardly any criminal activity beforehand [47]. However, their strong patriarchal-religious perception of honour is recognisable. It is important for advisors, police officers, physicians and psychotherapists to take down an exact record of the case history in its transcultural context duringany contact with advice centres, in medical-psychological investigations or in a case where a person affected reports the possible act to the police, prior to such a crime being committed [48]. For instance, by means of a special interview approach, the interviewer could ask questions to find out whether there was a rigid family structure and about the importance of honour for the family. Human rights organisations in the countries of origin are unambiguously and strictly against any reduced or commuted sentences for such perpetrators [49].

\section{Conclusion}

It shows that many prevention and support measures still need to be taken to prevent honour crimes both in the countries of origin and in migration. Not only the possible perpetrators, but also society as a whole must be involved, as they consciously or unconsciously create social pressure and tolerate these acts. In this context, it is necessary to change the traditional ideas of men, but also of women, which have been shaped for centuries: It must be made clear that no religion or tradition can justify crime in the name of honour. Only in a society in which both sexes live together on equal terms are the conditions given for crimes in the name of honour to be completely eliminated. Even if the legal aspect of the guilt principle, which is free of culturalist prejudices and simplifications, ensures that the same law applies to everyone and that the perpetrators are punished appropriately, the aspect of the crime as a violation of human rights must not be forgotten.

\section{References}

1. Kizilhan J (2004) Sozialisation im Krieg. In: Sommer G, Fuchs A (Hg.) Handbuch der Kriegs- und Friedenspsychologie. Wein- heim: Beltz S 357368.

2. Cooney M (2014) Death by family: Honour violence as punishment. Punishment \& Society 16: 406-427.

3. Baumeister W (2007) Ehrenmorde - Blutrache und ähnliche Delinquenz in der Praxis bundesdeutscher Strafjustiz; Reihe Kriminologie und Kriminalsoziologie - Band 2. Münster: Waxmann.

4. Doğan R (2014) Different cultural understandings of honour that inspire killing: An inquiry into the defendant's perspective. Homicide Studies 18: 363-388.

5. Terman RL (2010) To specify or single out: Should we use the term "honour killing"? Muslim World Journal of Human Rights 7: 1-39.

6. Kizilhan J (2006) Ehrenmorde - Der unmögliche Versuch einer Erklärung. Berlin: Regener

7. Kulczycki A, Windle S (2011) Honour killings in the Middle East and North Africa: A systematic review of the literature. Violence Against Women 17: 1442-1464.

8. Meyer N (2011) Parents question narrative of "honour killing" in daughter's death. The Arab American News.

9. Caffaro F, Ferraris F, Schmidt S (2014) Gender differences in the perception of honour killing in individualist versus collectivistic cultures: Comparison between Italy and Turkey. Sex Roles 71: 296-318.

10. Greco L (2012) Ehrenmorde im deutschen Strafrecht. Zeitschriftfür InternationaleStrafrechtsdogmatik

11. Hayes B, Mill CE, Freilich JD, Cermak SM (2018). Are Honour Killings Unique? A comparision of honour killings, domestic violence homicides by far-right extermists. Homicide Studies 22: 70-93

12. Sozial- und Bildungszentrum (TAREM) (2008) Gökyüzünde Asılı Çığlıklar Namus/Töre Cinayetlerine Işık Tutuyor, Bericht des Bürgermeisteramtes Baglar. Diyarbakir

13. BKA (2011) Bundeskriminalamt

14. Eisner M, Ghuneim, L (2013) Honour killing attitudes amongst adolescents in Amman, Jordan. Aggress Behav 39: 405-417.

15. Ünsal A (1985) Family Ties Versus Law - The Blood feud Tradition in Turkey. In: Türköz E (Hg.) Family in Turkish Society - Sociological and Legal Studies. Ankara: Turkish Social Science Association 221 -245.

16. Doğan R (2011) Is honour killing a "Muslim phenomenon"? Textual interpretations and cultural representations. Journal of Muslim Minority Affairs, 31: 423-440. 
Citation: Kizilhan JI. The Impact of Culture and Belief in So-Called Honour Killings A Comparative Study between Honour Murders and other Perpetrators of Violence in Germany. 2019; 7(1): 7.

17. Heckhausen H, Gollwitzer PM (1987) Thought contents and cognitive functioning in motivational versus volitional states of mind. In: Motivation and Emotion 11: 101- 120.

18. Kornadt HJ (1974) Toward a Motivational Theory of Aggression and Aggression Inhibition: some Considerations about an Aggression Motive and their Application to TAT and Catharsis. In De Wit J, Hartup WW (Hg.) Determinants and Origins of Aggressive Behavior. Den Haag: Mouton

19. Simons D (1988) Tötungsdelikte als Folge mißlungener Problemlösungen. Stuttgart: Verlag für Angewandte Psychologie.

20. Werbik H (1978) Handlungstheorien. Stuttgart: Kohlhammer.

21. Lempp R (1977) Jugendliche Mörder. Eine Darstellung an 80 vollendeten und versuchten Tötungsdelikten von Jugendlichen und Heranwachsenden. Bern: Huber.

22. Dietz ML (1983) Killing for Profit. The Social Organization of Felony Homicide. Chicago: Nelson-Hall.

23. Servay W, Rehm J (1986) Bankraub aus Sicht der Täter: täter- leitende Faktoren bei Raubüberfällen auf Geldinstitute. Wies- baden: Mittelbayerische Druckerei- und Verlagsgesellschaft

24. Amir M (1971) Patterns in forcible rape. Chicago: University of Chicago Press.

25. Volbert R (1990) Tötungsdelikte im Rahmen von Bereicherungstaten Dissertation. Berlin: Technische Universität

26. Burgheim J (1993) Psychologische Bedingungen bei Entstehung und Verlauf von Tötungsdelikten in der Situation der Partnertrennung. Dissertation. Konstanz: Hartung-Gorre

27. Steck P, Matthes B, Wenger de Chavez C, Sauter K (1997) Tödlich endende Partnerkonflikte. In: Monatsschrift für Kriminologie und Strafrechtsreform 80: 404-417.

28. Steck P, Raumann M, Auchter U (2005) Psychologische Bedingungen des Sexualmordes. In: Monatsschrift für Krimino- logie und Strafrechtsreform 88: 70-81.

29. Megargee El (1982) Psychological determinants and correlates of crimina violence. In: Wolfgang ME, Weiner NA (Hg.) Criminal Violence. Beverly Hills: Sage Publications 81-170.

30. Göppinger H (1976) Kriminologie. München: Beck

31. Baier D, Pfeiffer C (2007) Gewalttätigkeit bei deutschen und nichtdeutschen Jugendlichen - Befunde der Schülerbefragung 2005 und Folgerungen für die Prävention. Hannover: Kriminologisches Forschungsinstitut Niedersachsen e. V. (KFN).

32. Erbil B (2008) Toleranz für Ehrenmörder? Soziokulturelle Motive im Strafrecht unter besonderer Berücksichtigung des türkischen Ehrbegriffs. Berlin: Logos.
33. Erez E (1980) Planning of crime and the criminal career: official and hidden offenses. In: Journal of Criminal Law \& Crimino- logy 71: 73-77.

34. Feeney F (1986) Robbers as Decision-Makers. In: Cornish DB, Clarke RV (Hg.) The Reasoning Criminal: rational choice perspectives on offending. New York: Springer S. 53-71.

35. Kahlert TH, Lamparter U (1979) Tötungsdelikte bei Jugendlichen und Heranwachsenden. In: Monatsschrift für Kriminologie und Strafrechtsreform 62: 206-217.

36. Göppinger H (1975) Homicide and Criminal Carreer. A First Provisional Report of the Investigations of Murderers at Tübin- gen. In: Rassegna di Criminologia 6: 39-45

37. Hirsi Ali A (2005) Ich klage an. Plädoyer für die Befreiung der muslimischen Frauen. München \& Zürich: Piper.

38. Kizilhan J (2002) Konflikte und Konfliktlösungen in patriarchalischen Gemeinschaften am Beispiel der Solidargruppen in Ostanatolien. In: conflict \& communication online 1: 1 .

39. Terres des Femmes (2006) Zwangsheirat - Lebenslänglich für die Ehre. Tübingen: Eigenverlag

40. United Nation (2010) Pressrelease on the 04.03.2010 (UN- RIC/317)

41. Uskel AK, Cross SE, Sunbay Z, Gercek-Swing B, Ataca B (2012) Honour bound: The cultural construction of honour in Turkey and the Northern U.S. Journal of Cross- Cultural Psychology, 43: 1131-1151.

42. Smettan JR (1992) Kriminelle Bereicherung in Abhängigkeit von Gewinnen, Risiken, Strafen und Moral. Freiburg: Eigenverlag Max-Planck-Institute.

43. Sannemüller U, Ullrich S, Pillmann F, Draba S, Marneros A (1999) Tötungsdelikte - soziodemographischer Hintergrund der Täter und tatspezifische Merkmale. In: Archiv für Kriminologi 65-74.

44. Shier A, Shor E (2016) "Shades of foreign evil," "honour killings," and "family murders"in the Canadian press. Violence Against Women 22: 1163-1188.

45. Kizilhan J (2008) Islam, Migration und Integration: Konflikte jugendlicher Migranten mit islamischem Hintergrund. In: conflict \& communication online 7: 1 .

46. Hasan M. (2002). The politics of honour: Patriarchy, the state and the murder of women in the name of family honour. The Journal of Israeli History, 21: 1-37.

47. Wikan U (2008) In honour of Fadime: Murder and shame. Baltimore, MD: Johns Hopkins, University Press.

48. Bühl A, Zöfel P (1995) SPSS für Windows Version 6.1 - Praxisorientierte die moderne Datenanalyse. Bonn: Addison-Wes- ley Publishing Company.

49. Heininger B (2009) Ehrenmord und Emanzipation: Die Geschlechterfrage in Ritualen von Parallelgesellschaften. Berlin: Lit Verlag. 